\title{
HYGIENE CONDITIONS AND ANIMAL- ENVIRONMENT RELATIONS IN FARM ANIMALS BARNS
}

\author{
Müge ERKAN CAN ${ }^{*}$ \\ ${ }^{1}$ Çukurova University, Faculty of Agriculture, Department of Agricultural Structures and Irrigation, 01330, \\ Adana, Turkey
}

Received: October 02, 2019; Accepted: January 07, 2020; Published: April 01, 2020

\begin{abstract}
In all type farms, animal health and the environment represents a major component, besides feeding, genetics and management quality. A healthy animal can only be grown in health and hygienic conditions. Health and environmental hygiene should not be ignored feature of the all types of farm production process quality. Animal health and care can be solved by prevention applications, vaccination strategies, disease reduction precautions and risk management approaches. Animal health - care management strategies and risk applications, several animal hygiene issues, have not been widely adopted and it is not known to most businesses yet. Appropriate animal health-care takes into consideration not only the zootechnical and veterinary affairs, but also the disease aspects and environmental hygiene conditions, economic relevances and furthermore product-production process quality related features. Enterprise-level hygiene covering all farm units is an important indicator of welfare for farm animals and is mostly dependent on facilities, management strategies of enterprise owners, climate conditions, and the behavior of the animals. According to the information given above, the objective of this study is to determine the associations between farm animal (cattle, sheep and chicken) behaviors, barn hygiene, animal hygiene, environmental conditions and the qualities of experiencing in Turkey.
\end{abstract}

Keywords: Farm animals, Animal barns, Environment, Hygiene conditions

*Corresponding author: Çukurova University, Faculty of Agriculture, Department of Agricultural Structures and Irrigation, 01330, Adana, Turkey

E mail: merkan@cu.edu.tr (M.E.CAN)

Müge ERKAN CAN (iD https://orcid.org/0000-0002-0744-1496

Cite as: Can ME. 2020. Hygiene conditions and animal-environment relations in farm animals barns. BSJ Eng Sci, 3(2): 64-70.

\section{Introduction}

Animal hygiene is an interdisciplinary science which the part of the veterinary and zoology sciences and it is relying on knowledge of varying demands of animals describes the preconditions of health preservation and investigates by adverse environmental effects. The expression also describes the multilateral effects of housing and nutrition on health, behavioral characteristics of farm animals, production economy and on the rural environment. Theoretical and practical knowledge of animal hygiene is based on nutrition, microbiology, animal physiology, husbandry and immunology. On this basis, animal hygiene applies the preventive veterinary measures with considering consequences. Animal hygiene also covers detailed with herds and health protection of them. At the same time, it contributes to the better understanding of monitoring of 
performance, management and technique of feeding and watering, air quality and ventilation, technique of manure handling and hygiene, cleaning and disinfection, risk factors affecting animals, medicine and food inspection and state animal husbandry. From the information provided, it is necessary to evaluate the hygiene conditions of livestock and whether there is a relationship between hygiene and environmental conditions.

\section{Cattle Barns}

The hygienic status of barn surroundings and the various hygienic measures carried out in cattle barns are important because environmental hygiene can affect yield quality and quantity directly. The hygiene of dairy cows can be used as a determiner of animal welfare, as it provides information about the quality of life of the farm facilities and the quality of the animals (Hultgren and Bergsten, 2001). Most studies those evaluated the hygiene of dairy cows were performed with animals housed in freestalls and confirmed that the cows' hygiene level is an important determiner of their welfare and that it is influenced by the characteristics and conditions of the facilities where they are lived (Nielsen et al.1997; Hultgren and Bergsten, 2001; Zdanowicz et al., 2004; Zurbrigg et al., 2005; De Palo et al., 2006; Sant'Anna and Paranhos da Costa, 2011). Poor hygiene conditions in cows would be associated with an increased occurrence of disease such as environmental mastitis (Schreiner and Ruegg, 2003).

Several factors affect the cleanliness conditions of the cattle. These factors can be classifield as air humidity, type of housing, material and construction of the floors, stall dimensions, use and amount of bedding, manure consistency, maintenance of the floors and cleaning of the animals (Ruud et al., 2011; Hauge et al., 2012). Silage is one of the potential contamination sources in cattle barns (Driehuis, 2013). Kymäläinen and Kuisma (2014) observed that the feeding troughs and drinking bowls were rather highly contaminated due to the contact with animals and silage. In the study, where the analysis of the water samples taken from the drinking waterlines of cattle barns, some values were observed to be much different from each other. The main and apparent causes of the differences are the current state of drinking water net in the enterprise and their possibility of being affected by different organic substances such as animal wastes. However, the secondary causes for drinking water pollution may be different, variable and be specific in any enterprises. Therefore, cattle barn hygiene conditions should be checked continuously and periodically, and necessary analyzes should be performed (Erkan Can, 2019). In the scope of the project where animal drinking water quality was investigated in Adana, Turkey, the images taken from cattle troughs are shown in Figure 1.

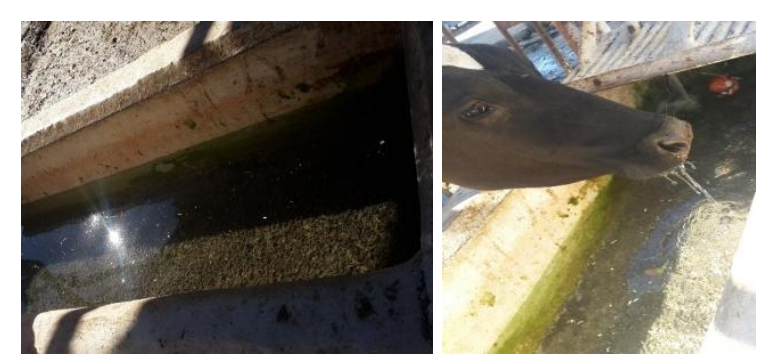

Figure 1. Water troughs for cattle.

Biosecurity factor and control of infectious agents should be examined in farm management. Biosecurity is a series of management practices and an essential aspect which designed to minimize or prevent and control infectious disease agents in to a farm for environment and human health.

Pseudomanas spp. is gram negative bacteria which is widespread in the environment of the dairy cow (drinking troughs, teats, feed etc.) because they need few nutrients to multiply or grow and they can survive in the moist environments (Kirk and Mellenberger, 2001). Some pathogens (Klebsiella spp. and Enterobacter spp.) also populate soil, feed and if moisture in the environment of the cow increases populations of them also increase (Hogan, 2005).

Many studies show that mastitis which caused by number of different bacteria is an inflammatory disorder which can be end in death and it is most widespread health problem in dairy cows. In the study which to determine herd udder health and milk quality status of dairy farms in Northern Cyprus, somatic cell counts were measured and bacteriological isolations were performed monthly for one year in bulk tank milk belonging to 138 dairy farms (Darbaz et al., 2018). In the study show that there are important widespread udder health problems in many herds (bulk tank milk somatic cell count $>400.000$ cells/ml in 74\%) in Northern Cyprus, and that the mastitis control methods are of poor quality or are insufficient. These results led been to consider that subclinical mastitis levels are higher in dairy farms. According to the study conducted in Southern Ontario, Canada; environmental bacteria, including Escherichia coli, Klebsiella spp. and Streptococcus uberis are a common cause of clinical mastitis in dairy cows (data were collected from 59 dairy farms) (Levison et al., 2016). The risk of mastitis is depend on both animal and the environmental factors generating in farms. Causal organisms are generally classified as either environmental or contagious. The reservoir for contagious is the udder, whereas environmental pathogens are those that survive in the outer environment such as bedding and manure (Harmon, 1994). The most common contagious pathogens are listed Table 1 (O’Driscoll, 2009). 


\section{Black Sea Journal of Engineering and Science}

Table 1. Mastitis causing agents (listed by method of transmission)

\begin{tabular}{|c|c|c|}
\hline Mastitis Pathogen & Type & $\begin{array}{l}\text { Typical infection } \\
\text { severity/pattern }\end{array}$ \\
\hline $\begin{array}{l}\text { Staphylococcus } \\
\text { aureus }\end{array}$ & $\mathrm{C}$ & $\begin{array}{l}\text { Prolonged elevatec } \\
(\mathrm{SCC}),(\mathrm{SCM} / \mathrm{CM})^{1}\end{array}$ \\
\hline $\begin{array}{l}\text { Streptococcus } \\
\text { agalactiae }\end{array}$ & $\mathrm{C}$ & SCM and $\mathrm{CM}^{2}$ \\
\hline $\begin{array}{l}\text { Corynebacterium } \\
\text { bovis }\end{array}$ & $\mathrm{C}$ & $\mathrm{SCM}^{2 ; 3}$ \\
\hline $\begin{array}{l}\text { Coliforms e.g. E.coli, } \\
\text { Klebsiella spp., } \\
\text { Enterobacter spp. }\end{array}$ & $\mathrm{E}$ & CM with SCC $1 ; 2$ \\
\hline Pseudomonas spp. & $\mathrm{E}$ & SCM and $\mathrm{CM}^{2 ; 4}$ \\
\hline $\begin{array}{l}\text { Actinomyces } \\
\text { pyogenes }\end{array}$ & $\mathrm{E}$ & $\mathrm{CM}^{2 ; 5}$ \\
\hline Serratia spp. & $\mathrm{E}-\mathrm{C}$ & Chronic CM $2 ; 6$ \\
\hline $\begin{array}{l}\text { Streptococcus } \\
\text { dysgalactiae, } \\
\text { S.uberis, S.bovis }\end{array}$ & $\mathrm{E}$ & $\mathrm{CM}^{2 ; 7}$ \\
\hline $\begin{array}{l}\text { Enterococcus } \\
\text { faecium, E.faecalis }\end{array}$ & $\mathrm{E}$ & $\mathrm{CM}^{2} ; 8$ \\
\hline $\begin{array}{l}\text { Coagulase-negative } \\
\text { Staphylococci }\end{array}$ & SF & $\operatorname{SCM}^{9 ; 2}$ \\
\hline
\end{tabular}

$\overline{\mathrm{SCC}}=$ somatic cell count, $\mathrm{C}=$ contagious, $\mathrm{E}=$ environmental, $\mathrm{SF}=$ skin flora opportunists, SCM/CM= sub/clinical mastitis

1= De Haas et al., 2002; 2= Harmon, 1994; 3= Honkanen-Buzalski et al., 1984; 4= Kirk and Bartlett, 1984; 5= Jonsson et al., 1991; 6= Hogan and Smith, 2003; 7= Smith et al., 1985; 8= PeterssonWolfe et al., 2007; 9= Davidson et al., 1992.

Evaluating how diseases are introduced to the differs for each disease. Ways that some diseases are presented in Table 2 (BAMN, 2001).

Sant'Anna and Paranhos da Costa (2011) carried out a study were to describe how the hygiene conditions of dairy cows vary over time and to assess whether a relationship exists between hygiene and somatic cell count (SCC) in milk. They conducted monthly hygiene evaluations on lactating cows in two dairy farms for 9 consecutive months, totaling 3554 evaluations from 545 animals. They observed that most critical months for cow hygiene were rainfall, when a reduction in the welfare of cows and higher SCC values. Also, researchers suggested that the evaluation and control of dairy cow hygiene are useful in defining management strategies to reduce problems with milk and improve the welfare of the animals.

DeVries et al. (2012) studied to determine the associations between dairy cow standing and lying behavior, barn hygiene, cow hygiene and the risk of experiencing elevated SCC on 69 lactating Holstein dairy cows those housed in a sand-bedded, freestall barn with a free cow traffic automatic milking system. Study results show that cow hygiene is affected by the standing and lying behavior of cows and by the cleanliness of the cow's environment. Researchers emphasize the need for cows to be provided clean lying and standing environment. The study results also show that frequent cleaning of barn alley floors will help improve cow hygiene.
Cattle barn environments not only involve the separated areas hygiene but also include a combination of different rooms and levels of hygiene physically. For this reason, hygiene conditions of cattle barns must be taken in to attention as whole farm. Kymäläinen and Kuisma (2014) tested the suitability of microbiological dipslide methods to measure the hygiene level of the environmental surfaces in a cattle barn. A total of 1112 measurements were carried out during five measurement days. At the end of the study they detected that the poorest hygiene level was observed in the barn (closed area where animal live) and the second dirtiest in the washing room. The corridor and personnel rooms had the highest hygiene status. The office and personnel kitchen and the milk room were generally the next cleanest, depending on the evaluation criteria.

Environmental hygiene also refers to other environmental problems such as dust, bad smells, air pollutants which are caused by storage and utilization of animal residues. Air pollutants in cattle barns also affect the safety of the environment, as well as the welfare and performance of animals and workers (Hartung and Schulz, 2011).

A research was conducted to determine the biosecurity conditions of cattle farms in Malatya and 172 breeders were interviewed by using the random sampling method in selected cattle farms in specific districts (Köseman and Şeker, 2016). When animal health and shelter hygiene conditions were evaluated, it was determined that several parameters were "acceptable", however, the others were considerably insufficient. The research stated that precautions should be taken to obtain profitability, sustainable production and public health immediately and controlling farms for biosecurity and vaccination programmers should efficiently be conducted and also administrative sanctions must be applied when needed.

According to a study which conducted in 60 dairy herds study showed a correlation between dirty cattle presented for slaughter and animal dirtiness on-farm (Hauge et al., 2012). In total, 56 factors were examined, of which the 19 most important factors are given detailed in the study (such as animal cleanliness, manure scores, management and environmental factors). Researchers emphasized that factors associated with dirty animals were, in ranked order, high air humidity, animal type (heifers and bulls/steers), housing (freestalls and pens without bedding), manure consistency and lack of efforts directed toward cleaning the animals throughout the year. Besides, additional factors about dirty animals in the dirty herds were found as water leakage from drinking nipples/troughs into lying areas, bedding type, and feed type.

Lamsal (2018) pointed out that prevalence of subclinical mastitis was high in cows with increasing hygiene score of rear body parts (lower leg, upper leg, flank and udder) that is with increasing unhygienic condition. For assessment of cow udder, rear \& font part, hygiene 


\section{Black Sea Journal of Engineering and Science}

standard method outlined by Reinemann and Cook, 2007 was used. Three main body parts of animal mentioned above were marked by the researcher, with scores; 1 for the cleanest of all, 2 for the one with dirt in $2-10 \%$ surface area, 3 for the one with $10-30 \%$ surface dirt and 4 for more than $30 \%$ of the dirt was marked to follow. The overall prevalence rate was reported as $69 \%$ in cattle. In the study, three main body parts of animal were marked with scores methodology. Udder was competitively cleaner than rear and flank regions. Mean hygiene score of cow was 2.4 with udder, lower leg and flank being 2.80, 2.42 and 2.64 respectively. Data analysis showed one of the strong reasons for subclinical mastitis was poor hygienic status of animal and housing system. In the pictures given below are images on the related subject which from our studies in Turkey (Figure 2).

Table 2. Transmission of key bovine pathogens

\begin{tabular}{|c|c|c|c|c|}
\hline & Staphylococcus aureus & Johne's disease & $\mathrm{BVD}^{*}$ & Salmonella spp. \\
\hline \multicolumn{5}{|l|}{ Transmission via: } \\
\hline Fecal-oral & - & $\mathrm{x}$ & $\mathrm{X}$ & $\mathrm{x}$ \\
\hline Nasal secretions/saliva & $?$ & - & $\mathrm{x}$ & $\mathrm{x}$ \\
\hline Milk & $\mathrm{x}$ & $\mathrm{x}$ & $\mathrm{x}$ & $\mathrm{x}$ \\
\hline In utero & - & $\mathrm{x}$ & $\mathrm{x}$ & $\mathrm{x}$ \\
\hline Sexual & - & - & $\mathrm{x}$ & - \\
\hline Incubation period & Days-months & Years & 5-10 days & 1-4 days \\
\hline Duration of clinical disease & Days-years & Weeks-months & 2 weeks & 1-7 days \\
\hline Duration of shedding & Days-years & Months-years & 10-14 days & Weeks-months \\
\hline Survival in environment & $?$ & Months-years & Up to 14 days & Months \\
\hline Growth in environment & Yes & No & No & Yes \\
\hline
\end{tabular}

*BVD = bovine virus diarrhea

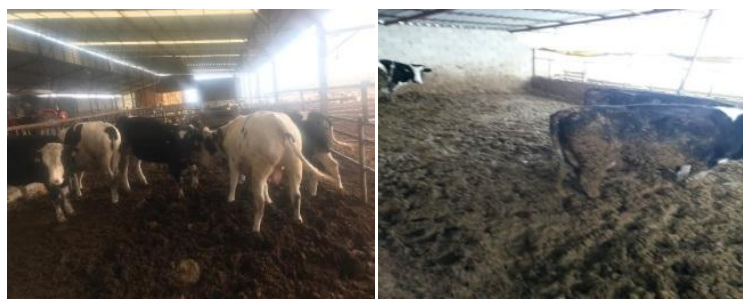

Figure 2. Unclean cattle barns

\section{Sheep Husbandry}

As a species extensively managed traditionally at least for some of the year, sheep have received relatively little attention from a welfare perspective. Sheep welfare can be considered from the frame of the animals biological functioning, the naturalness of the way in which they are kept. These different fields can be integrated by considering the animal and the environment (Dwyer, 2009).

Basics of the sheep environmental factors are extreme climatic conditions (extreme moisture, bad ventilation, draughts, and temperature extremes particularly at lambing and weaning), transportation and faulties during transportation, shearing and housing types. Sheep and goats share many health problems while there are some important differences between the species. Diseases of sheep and goats may not always be apparent in the early stages of illness, so barn owners should regularly monitor their animals for signs of illness and should check environmental hygienic conditions. So many of the diseases that affect sheep cannot be detected easily by external examination of the sheep and they occurs because of bad hygienic conditions. Sheep may well be infested with small numbers of sheep scab mites or lice.
Sheep and goats are vulnerable to several serious diseases including; bluetongue, brucellosis, foot and mouth disease, goat pox, lead poisoning etc.

Shepherds should pay particular attention to cleanliness and hygiene of equipment and pens during pregnancy and lambing. Attention to cleanliness and hygiene is also important in the lambing area. Lambing area floors should be dry and well-drained. Additionally in all areas of sheep farms, dry, clean, comfortable conditions under foot should be provided to minimize footrot and hygiene problems (CRWL, 2000).

Purchasing replacements and mixing of sheep from several herds can bring new disease to the farm. Most diseases of contagious are introduced into farms when new animals are added. If a closed herd is not possible, it should be used an animal quarantine program. A useful quarantine program consists of a process and area that prevents co-mingling of animals for at least 30 days, including separate water supplies. Useful biosecurity applications and healthy and hygienic environmental conditions are a vital part of keeping disease away from the animal and these situations will also protect the health of the workers and any members of the public who may visit the farm or consuming of sheep products. Restricting and controlling movements of people, vehicles and equipment into areas where sheep or goats are kept, cleaning and disinfecting equipment and vehicles, protective clothing and footwearis are vital part of a good biosecurity programme.

Some diseases may occur when sheep graze different plants such as cape weed, oats, canola, wild turnip or young plants which have high nitrate concentrations. Sheep should not be grazed with plants with high nitrate levels and care should be taken to the surrounding 
vegetation. In sheep farms or grazing areas, all fields and buildings should be kept clear of debris such as wire or plastic, which could be harmful to sheep. When sheep are outdoors in winter, and especially when fed on root crops, they should be allowed either to turn back to pasture or to a straw bedded space. This space gives a more comfortable lying area as well as limiting the build-up of mud or dung on the fleece (CRWL, 2000).

Conditions that favour spread of disease are by and large those conditions that also have a potential adverse effect on animal welfare such as poor hygiene, overcrowding, rapid changes in temperature or weather conditions and unsuitable shelter (Roger, 2008). In a study about sheep housing and hygiene conditions, the effects on the health and welfare of sheep were discussed with regard to free access to external areas, to exposure to solar radiation, to ventilation and light regimes, to indoor climate and hygiene and to noise (Caroprese, 2008). Results provided information about the relationship between poor housing conditions, sheep welfare and problems of udder health with increased risk of mastitis and reduced yield and quality of milk.

Although the studies investigating the relationship between hygiene and yield in sheep breeding are limited, studies conducted in this field have concluded that hygienic conditions affect yield positively. In a study conducted by Alexopoulos et al.(2011), purpose was to survey the raw ovine milk produced in sheep farms of Greece and to explore the role of various factors on its quality thus contributing on the research on improving milk safety. A total of 155 samples from 21 farms were analyzed for TBC (total bacterial count) and half of them for the rest of bacteria. As their results show as an average was TBC: $5.48 \log \mathrm{cfu} / \mathrm{mL}$, SCC: $6.05 \log$ cells $/ \mathrm{mL}$, coliforms: $4.49 \log \mathrm{cfu} / \mathrm{mL}, \mathrm{S}$. aureus: $3.94 \log \mathrm{cfu} / \mathrm{mL}$, environmental streptococcal counts: $4.95 \log \mathrm{cfu} / \mathrm{mL}$ and PIC: $5.7 \log \mathrm{cfu} / \mathrm{mL}$. Even if some of the results were in accordance with the standard values, some results were reported to be more than the required values. At the end of the study, researchers indicated that most of the factors concern simple sanitation practices which if properly adopted by the farmers have proven their value and ensure a better outcome of milk quality.

\section{Poultry Rearing}

In Turkey, poultry-meat products continue to be a major nutriment of human consumption. Due to it is more accessible than red meat, chicken meat can reach high consumption amounts. In the management of poultry houses a high degree of cleanliness, hygiene standards, clean and healthy water and feed should be the first care. However, poultry production and slaughtering farms, which in unsuitable hygiene conditions, pose a serious health hazard. The organisms in chicken meat could be readily transmitted to man in the handling of raw poultry, either directly or via another food item. Disease is a major hazard in poultry houses, especially in large scale enterprises which has huge number of animals. Hygiene is a most important factor in disease prevention. Efficient farm management and suitable hygienic conditions can eliminate over $90 \%$ of all diseases and prevent disease and its spread among the flock.

Hygiene, sanitation and biosecurity play a major role in any effective disease control programme and high yield for poultry production enterprises. Poor levels of biosecurity will lead to a higher prevalence of disease in the case of haemolytic Gallibacterium spp. and a higher risk of flocks getting infected with thermophilic Campylobacter spp. or Salmonella spp. (Gibbens et al., 2001; Liljebjelke et al., 2005; Bojesen et al., 2010; Osimani et al., 2017).

In principle, the hygiene problems of poultry operation are similar to those experienced with other meat animals, but certain features make control of microbial contamination more difficult with poultry. Because of the rapid rate of processing, which may reach more than thousands birds/h on some lines, conditions support the spread of microorganisms (Mead, 1995)

Gibbens et al. (2001) indicated that a standard hygiene protocol followed by all staff that entered in a broiler farm could reduce the risk of a flock getting infected with thermophilic Campylobacter spp. by $50 \%$. This hygiene protocol included a strict process with boot dips before entering the poultry houses and farm specific clothing which also demonstrates the importance of a specific farm and poultry house hygiene lock in preventing (zoonotic) pathogens from entering a broiler house.

Van de Giessen et al. (1998) studied on two Dutch broiler farms to understand transmission routes of Campylobacter spp. in broilers and possibilities for prevention of infections. Isolates of Campylobacter spp. were typed by using randomly amplified polymorphic DNA (RAPD) analysis. The data indicate that broiler flocks become infected from environmental sources and according the other data suggest that on one farm transmission of Campylobacter spp. occurred from cattle to broilers via the farmer's footwear. The results indicate that the application of hygiene measures significantly reduced campylobacter infections of broiler flocks on both farms.

Folorunso et al. (2014) subjected a study to a 7-day which involved the monitoring of poultry farm hygiene. They took samples from water troughs from deep litter and caged chicken water troughs (drinkers) in three different poultry farms. Drinkers were washed before filling with water on Day 1. For Days 3, 5 and 7 water was served without prior washing. End of the study they found that those left for 3, 5 and 7 days uncleaned had progressively high bacterial loads. Researchers suggesting that the flock of birds and the consumers of the eggs and meat from the chickens are at risk of bacterial infection unless strict farm hygiene is ensured through regular monitoring.

It was showed that an increased frequency of sanitizing the watering lines was associated with higher flock 
performance by Tablante et al. (2002). This result suggests that an obvious benefit from improving inner biosecurity might be an important incentive for poultry farmers to implement a higher standard of hygiene in the broiler house.

Deep litter and raised netting flooring systems in broiler houses were compared for their effects on air quality and bird health during an 8-week growing period and weekly measurements were taken of respirable dust, numbers of airborne microorganisms and concentrations of gaseous pollutants by Madelin and Wathes (2007). They empathized that respirable dust concentrations and numbers of airborne microorganisms were significantly higher in the litter rooms and birds on litter were observed to have a higher incidence of lung damage and more of the birds on litter had viable microorganisms present in the lungs at necropsy.

Poultry premises and farm buildings should conform to requirements for isolation from the environment and strict observance of principles of hygiene and disease prevention (e.g. restrictions on movement of staff and vehicles). A poultry site must be prepared regularly for the entry of each new group as; removal of birds, litter and manure; dry and wet cleaning; vector and rodent control; disinfection; fumigation. Special care should be exercised in the performance of sanitary procedures after a disease outbreak. Immediate disposal of dead and diseased birds is an serious and effective tool in preventing the spreading of any disease. Regular visual inspection and routine microbiological testing, is very effective in checking the efficacy of cleaning and disinfection (Meroz and Samberg, 1995).

\section{Results}

Nowadays, many important developments and legal regulations have been applied about animal hygiene conditions and animal welfare situations in European Union member countries. New approaches related to animal hygiene in farm animals should became topical subjects in Turkey as parallel to developments in the world.

Animal welfare and hygiene standards in Turkey criteria should become a legal obligation. Existing relevant legislations, regulations and laws should be reviewed and developed or rearranged. Necessary investigations should be carried out meticulously and sanctions should be applied. Hygiene and disease prevention precautions should aim at (FAO and OIE, 2010);

- Maintaining the hygiene and safety of all facilities in farms.

- Preventing contact between healthy animals and potentially infected animals.

- Provide the all workers health on the farm and the implementation of hygienic working procedures.

- Reducing contact between livestock and professional or other visitors, and taking all hygienic measures necessary to minimize the possible introduction of pathogens and contaminants (e.g vehicles).

- Ensuring overall health of livestock through good nutrition, providing pure drinking water and reducing stress.

- Keeping records of animal populations and making observations and analyses periodically in facilities/on farms.

\section{Conflict of interest}

The author declare that there is no conflict of interest.

\section{Acknowledgements}

This study was supported by Cukurova University Scientific Research Projects Unit (FBA-2017-7450) and published in the Procceding book of International Congress on Domestic Animal Breeding Genetics and Husbandry-19 (ICABGEH-19).

\section{References}

Alexopoulos A, Tzatzimakis G, Bezirtzoglou E, Plessas S, Stavropoulou E, Sinapis E, Abas Z. 2011. Microbiological quality and related factors of sheep milk produced in farms of NE Greece. Anaerobe 17: 276-279.

BAMN, 2001. An introduction to infectious disease control on dairy farms (biosecurity) \& biosecurity on dairies. Bovine Alliance on Management and Nutrition (BAMN). Biosecurity on Dairies.

Bojesen AM, Nielsen SS, Bisgaard M. 2010. Prevalence and transmission of haemolytic Gallibacterium species in chicken production systems with different biosecurity levels. Avian Pathol, 32: 503-510

Caroprese M. 2008. Sheep housing and welfare. Small Rumin Res, 76 (1-2): 21-25.

CRWL, 2000. Code of Recommendations for the Welfare of Livestock; Sheep. https://assets.publishing.service.gov.uk/government/upload s/system/uploads/attachment_data/file/69365/pb5162sheep-041028.pdf (accessed date, July 01, 2019).

Darbaz İ, Baştan A, Salar S. 2018. Investigation of udder health and milk quality parameters of dairy farms in Northern Cyprus. Part I: SCC and bacteriologic examination. Ankara Üniv Vet Fak Derg, 65: 145-154,

Davidson TJ, Dohoo IR, Donald AW, Hariharan H, Collins K. 1992. A cohort study of coagulase negaative staphylococcal mastitis in selected dairy herdss in Prince Edward Island. Canadian J Vet Res, 56: 275-280.

De Haas Y, Barkema HW, Veerkamp RF. 2002. The effect of pathogen-specific clinical mastitis on the lactation curve for somatic cell count. J Dairy Sci, 85: 1314-1323.

De Palo P, Tateo A, Zezza F, Corrente M, Centoducati P. 2006. Influence of free-stall flooring on comfort and hygiene of dairy cows during warm climatic conditions J Dairy Sci, 89: 45834595.

DeVries TJ, Aarnoudse MG, Barkema HW, Leslie KE, von Keyserlingk MAG. 2012. Associations of dairy cow behavior, barn hygiene, cow hygiene and risk of elevated somatic cell count. J Dairy Sci, 95: 5730-5739.

Dwyer CM. 2009. Welfare of sheep: Providing for welfare in an extensive environment. Small Rumin Res, 86 (1-3): 14-21. 


\section{Black Sea Journal of Engineering and Science}

Erkan Can M. 2019. Evaluation of animal drinking water quality of cattle enterprises. Fresenius Environ Bullet, 28 (4A): 3527 3535.

FAO and OIE, 2010. Food and Agriculture Organization of the United Nations (FAO) /World Organisation for Animal Health (OIE). Guide to Good Farming Practices for Animal Production Food Safety. Rome, 2010. FAO E-ISBN 978-92-5-006145-0 (pdf), OIE ISBN 978-92-9044-819-8.

Folorunso OR, Kayode S, Onibon VO. 2014. Poultry farm hygiene: microbiological quality assessment of drinking water used in layer chickens managed under the battery cage and deep litter systems at three poultry farms in southwestern Nigeria. Pakistan J Biol Sci, 17 (1): 74-79.

Gibbens JC, Pascoe SJS, Evans SJ, Davies RH, Sayers AR. 2001. A trial of biosecurity as a means to control Campylobacter infection of broiler chickens. Preventive Vet Med, 48: 85- 99.

Harmon RJ. 1994. Physiology of mastitis and factors affecting somatic cell counts. J Dairy Sci, 77: 2103-2112.

Hartung J, Schulz J. 2011. Occupational and environmental risks caused by bio-aerosols in and from farm animal houses. Agri Engin Inter: the CIGR J, 13: 1-8.

Hauge SJ, Kielland C, Ringdal G, Skjerve E, Nafstad 0. 2012. Factors associated with cattle cleanliness on Norwegian dairy farms. J Dairy Sci, 95(5): 2485-2496.

Hogan J. 2005. Controlling coliform mastitis. Proceedings of the British Mastitis Conference, Stoneleigh,p.5359.http://britishmastitisconference.org.uk/BMC2005Proocee ding (accessed date, July 01, 2019).

Hogan J, Smith KL. 2003. Coliform mastitis. Vet Res, 34: 507 519.

Honkanen-Buzalski T, Griffin TK, Dodd FH. 1984. Observation on Corynebacterium bovis infection of the bovine mammary gland. I. Natural infection. J Dairy Res 51: 371-378.

Hultgren J, Bergsten C. 2001. Effects of a rubber-slatted flooring system on cleanliness and foot health in tied dairy cows. Preventive Vet Med, 52: 75-89.

Jonsson P, Olsson SO, Olofson AS, Falth C, Holmberg O, Funke H. 1991. Bacteriological investigations of clinical mastitis in heifers in Sweden. J Dairy Res, 58: 179-185.

Kirk J, Mellenberger R. 2001. Mastitis control programme for Pseudomonas mastitis in dairy cows http://www.uwex.edu/MilkQuality/PDF/pseudomonas.pdf (accessed date, July 01, 2019).

Kirk JH, Bartlett PC. 1984. Nonclinical Psuedomonas aeruginosa mastitis in a dairy herd. J American Vet Med Assoc, 184: 671673.

Köseman A, Şeker İ. 2016. Current status of cattle farms in Malatya: II. Biosecurity applications in animal health and stable hygene perspective. Kocatepe Vet J, 9(2): 61-69.

Kymäläinen HR, Kuisma R. 2014. Hygiene of environmental surfaces in a cattle barn. Agri Engin Inter: the CIGR J, 16(1) $45-54$

Lamsal P. 2018. Cattle Hygiene Status and Its Relation with Subclinical Mastitis: A Study in Commercial Farms in Rampur, Nepal. Int J Applied Sci Biotech, 6(3): 252-254.

Levison LJ, Miller-Cushon EK, Tucker AL, Bergeron R, Leslie KE, Barkema HW, DeVries TJ 2016. Incidence rate of pathogenspecific clinical mastitis on conventional and organic Canadian dairy farms. J Dairy Sci, 99: 1341-1350.

Liljebjelke KA, Hofacre CL, Liu T, White DG, Ayers S, Young S,
Maurere JJ. 2005. Vertical and horizontal transmission of Salmonella within integrated broiler production system. Foodborne Pathogen Disease. 2: 90-102.

Madelin TM, Wathes CM. 2007. Air hygiene in a broiler house: Comparison of deep litter with raised netting floors. J British Poultry Sci, 30: 23-37.

Mead GC. 1995. Hygiene Problems and Control of Process Contamination. In: Mead G.C. (eds) Processing of Poultry. Springer, Boston, MA DOI: 10.1007/978-1-4615-2059-7_6 Online ISBN; 978-1-4615-2059-7.

Meroz M, Samberg Y. 1995. Disinfecting poultry production premises. Revue Sci Techniq, 14(2): 273-291.

Nielsen HL, Mogensen L, Krohn C, Hindhede J, Sorensen JT. 1997. Resting and social behaviour of dairy heifers housed in slatted floor pens with different sized bedded lying areas. Applied Anim Behav Sci, 54: 307-316.

O'Driscoll K. 2009. Effect of housing systems on Dairy Cow Hygiene and under health. Sustainable Animal Production. Wageningen Academic Publishers, The Netherlands. Pages 107-119. DOI: 10.390/978-90-8686-685-4 (accessed date, July 01, 2019).

Osimani A, Aquilanti L, Pasquini M, Clementi F. 2017. Prevalence and risk factors for thermotolerant species of Campylobacter in poultry meat at retail in Europe. Poultry Sci, 96: 3382-3391.

Petersson_wolfe CS, Wolf SL, Hogan JS. 2007. In vitro growth of Enterococci of bovine origin in bovine mammary secretions from various stages of lactation. J Dairy Sci, 90: 4226-4231.

Reinemann D, Cook N. 2007. A Tool Box for Assessing Cow, Udder and Teat Hygiene. University of WisconsinMadison. https://www.researchgate.net/publication/237580204

Roger PA. 2008. The impact of disease and disease prevention on sheep welfare. Small Rumin Res, 76: 104-111.

Ruud LE, Kielland C, Østerås 0, Bøe KE. 2011. Free-stall cleanliness is affected by stall design. Livestock Sci, 135(2-3): 265-273.

Sant'Anna AC, Paranhos da Costa MJR. 2011. The relationship between dairy cow hygiene and somatic cell count in milk. J Dairy Sci. 94:3835-3844.

Schreiner DA, Ruegg PL. 2003. Relationship between udder and leg hygiene scores and subclinical mastitis. J Dairy Sci, 86 3460-3465.

Smith KL, Todhunter DA, Schoenberger PS. 1985. Environmental mastitis: cause, prevalence, prevention. J Dairy Sci, 68: 15311553.

Tablante NL, Myint MS, Johnson YJ, Rhodes K, Colby M, Hohenhaus G. 2002. A survey of biosecurity practices as risk factors affecting broiler performance on the Delmarva Peninsula. Avian Dis, 46: 730-734

Van De G Iessen AW, Ilburg JJHC, Itmeester TWSR, Van Der Plas J. 1998. Reduction of campylobacter infections in broiler flocks by application of hygiene measures. Epidemiol Infect, 121: 57-66.

Zdanowicz M, Shelford JA, Tucker CB, Weary DM, Von Keyserlingk MAG. 2004. Bacterial populations on teat ends of dairy cows housed in free-stalls and bedded with either sand or sawdust. J Dairy Sci, 87: 1694-1701.

Zurbrigg K, Kelton D, Anderson N, Millman S. 2005. Tie-stall design and its relationship to lameness, injury, and cleanliness on 317 Ontario dairy farms. J Dairy Sci, 88: 3201-3210. 